\title{
Gastric cancer: Past, present and future
}

\author{
Annie On-On Chan MBBS MRCP, Benjamin Chun-Yu Wong MBBS MD MRCP, \\ Shiu-Kum Lam MD FRCP FRACP FACG
}

AO-O Chan, BC-Y Wong, S-K Lam. Gastric cancer: Past, present and future. Can J Gastroenterol 2001;15(7):469. 474. Gastric cancer remains a major cause of cancer mortality in the world. However, in the past 10 decades, the view of gastric cancer has been changing. This includes the unexplained decline in the incidence of the cancer, the proximal shift of the cancer in the stomach, the identification of Helicobacter pylori as an etiological agent, rapid development in molecular tumour biology, new treatment modalities and the adoption of mass screening for prevention. This article reviews the changing views of gastric cancer and the latest developments.

Key Words: Gastric cancer; Helicobacter pylori

\section{Cancer de l'estomac : passé, présent, avenir}

RÉSUMÉ : Le cancer de l'estomac reste toujours une cause importante de mortalité dans le monde. Toutefois, le contexte dans lequel se situe ce type de cancer a changé au cours des dernières décennies. Pensons, entre autres, à la diminution encore non expliquée de l'incidence du cancer de l'estomac, au déplacement proximal des lésions cancéreuses dans l'estomac, au rôle possible d'Helicobacter pylori comme facteur étiologique, aux progrès rapides réalisés en biologie moléculaire des tumeurs, aux nouvelles formes de traitement et à l'adoption de mesures de dépistage de masse aux fins de prévention. Le présent article fait un survol des changements observés dans le cancer de l'estomac et des derniers progrès réalisés dans le domaine.
W ith the rapid decline in the global incidence of gastric cancer from the 1930s to the 1970s, the discovery of Helicobacter pylori and the advancement in molecular biology, the view toward gastric cancer has been changing. Nevertheless, gastric cancer remains the second most common cancer in morbidity and mortality globally. This paper reviews the recent changes in the incidence and disease pattern, the concept of $\mathrm{H}$ pylori as the etiological factor, the development of molecular biology and the advance in treatment of gastric cancer.

\section{EPIDEMIOLOGY AND DISEASE PATTERN}

The incidence of gastric cancer has declined rapidly over the past few decades; this decline took place globally $(1-5)$. The cause for this decline in the incidence of gastric cancer is still a medical mystery, and occurred before the discovery and eradication of $\mathrm{H}$ pylori. The decline took place earliest in countries with low gastric cancer incidence such as the United States in the 1930s, whereas the onset of decline in countries with a high incidence such as Japan was slower. In China, the decline was less dramatic than in other countries. Zheng et al (6) reported that in Shanghai, despite an overall decrease in gastric cancer incidence, an increase had been observed in the oldest and the youngest groups, and a less remarkable decline was observed in women than in men. The rise in incidence of gastric cancer among those 25 to 34 years of age is noteworthy, because this may signal the introduction of new environmental factors; as well, the age of onset of developing gastric cancer in the Chinese population is younger than that in the Western population.

This mini-review was prepared from a presentation made at the 1998 World Congress of Gastroenterology, September 6 to 11, 1998, Vienna, Austria Department of Medicine, The University of Hong Kong, Queen Mary Hospital, Hong Kong

Correspondence: Professor Shiu-Kum Lam, Department of Medicine, The University of Hong Kong, Queen Mary Hospital, Pokfulam Road,

Hong Kong. Telephone +852-2855-3348, fax +852-2816-2863, e-mail hrmelsk@hku.hk

Received for publication October 1, 1999. Accepted October 6, 1999 
The diffuse and intestinal types of gastric cancer are classified by Lauren (7) as two biological entities that are different with regard to epidemiology, etiology, pathogenesis and behaviour. While there was a decline in the worldwide incidence of the intestinal type of gastric cancer in the past few decades, a gradual increase in the diffuse type to the overall incidence of gastric cancer, a gradual increase in the diffuse type was observed, which has accounted for approximately $30 \%$ of gastric carcinoma in some reported series (8).

An explosive increase in the incidence of gastric cancers confined to the cardia has been observed (9-12). A shift from distal to proximal stomach cancers was partially due to the decrease in distal cancers. Proximal tumours share demographic and pathological features with Barrett's associated esophageal adenocarcinoma and are more likely to occur in men; this parallels the male predominance in the increasing incidence of lower-third esophageal carcinoma. Proximal tumours differ from distal tumours in that they are not associated with a severe form of gastritis, characterized by atrophy and/or intestinal metaplasia. They tend to be more aggressive than those arising from distal sites. It has been proposed that environmental factors or chemical carcinogens, eg, cigarettes and alcohol, have been particularly associated with cardiac carcinoma (13). In fact, it has been proposed that carcinoma at the cardia is a different entity from the rest of the gastric carcinomas.

The incidence of gastric cancer varies with different geographic regions as well. A high incidence is noted in Asian countries such Japan, Korea and China; parts of Europe such as Ireland; and South American countries such as Chile and Columbia. A difference in incidence and mortality from north to south has been observed in several countries, with the northern prefectures having a higher mortality risk than those in the south. This gradient is particularly marked in the northern hemisphere (14-16); in the southern hemisphere, the mortality risk tends to be higher in the southern parts $(17,18)$. It appears that higher geographic latitudes are associated with a higher gastric cancer risk.

\section{ENVIRONMENTAL RISK FACTORS AND H PYLORI}

Risk of gastric cancer is associated with socioeconomic status. Subjects from a lower socioeconomic class had approximately twice as much risk of developing intestinal-type gastric cancer as subjects from a higher socioeconomic group $(1,14,19,20)$. On the contrary, proximal gastric cancers were associated with higher socioeconomic class (12).

Large epidemiological studies demonstrating the association between diet and gastric cancer were mainly based on the amount of food imported and produced rather than the actual food consumption (21). This does not take into account the losses during storage, distribution and consumption of food, nor any ethnic dietary differences. The association between $\mathrm{N}$-nitroso compounds and gastric cancer was summarized by Bartsch et al (22) in 1987. The risk of gastric cancer induced by $\mathrm{N}$-nitroso compounds has been demonstrated in animal experiments (23-25). An increase in gastric nitrite was observed in patients with intestinal metaplasia, dysplasia and gastric cancer (26-28). The use of nitrate-based fertilizers $(27,29,30)$ and pickled foods that contain nitrosated products $(31,32)$ has been shown to positively correlate with gastric cancer. High salt intake has been shown to damage stomach mucosa and increase the susceptibility to carcinogenesis in rodents (33-35). The positive correlation between nitrate intake, salt excretion and gastric cancer has recently been shown in the Intersalt study involving 24 countries from 39 populations (36).

The World Health Organization's International Agency for Research on Cancer has recently classified $H$ pylori as a group 1 or definite carcinogen (37). The etiological role of $\mathrm{H}$ pylori in gastric cancer was based on Correa's $(38,39)$ model: chronic atrophic gastritis to intestinal metaplasia, dysplasia and finally carcinoma. H pylori has been shown to be strongly associated with gastric atrophy and intestinal metaplasia (40-42). Large case control and cohort studies have shown the relationship between $H$ pylori and adenocarcinoma (41,43-46) in both the intestinal and the diffuse types of gastric cancer. $H$ pylori infection has been estimated to increase the risk of gastric cancer sixfold (47). Tsugane et al (48) found that in a Japanese population, higher salt intake correlated with a higher prevalence of $H$ pylori infection. It was postulated that gastric mucosal damage caused by high salt intake facilitated $H$ pylori infection. The gastric juice of $\mathrm{H}$ pylori-positive individuals had a lower concentration of vitamin $\mathrm{C}$ than $\mathrm{H}$ pylori-negative individuals, but the concentration returned to normal when $H$ pylori was eradicated (49). Therefore, vitamin C could play an important role in preventing the damage caused by $\mathrm{H}$ pylori through its antioxidant effect (49). Lower socioeconomic status was associated with a higher prevalence of $\mathrm{H}$ pylori (50). However, large interventional studies are needed to directly prove the causative role of $\mathrm{H}$ pylori in gastric carcinogenesis (51). On the other hand, the association of $\mathrm{H}$ pylori with cancer of the gastric cardia is more controversial $(41,43,44,52)$.

Despite the proposal of dietary and environmental factors, and the identification of $\mathrm{H}$ pylori, the rapid global decline in gastric cancer is still not fully explainable. An interesting hypothesis that has been proposed as a pivotal point for the decline is the popularization of refrigerators $(53,54)$. Refrigerators improve the storage of food, thereby reducing salting for preserving food, and preventing bacterial and fungal contamination of food. Refrigeration also enables fresh food and vegetables to be more readily available, which may be a valuable source of antioxidants important for cancer prevention.

\section{MOLECULAR BIOLOGY}

Recent advances in molecular biology lead to a better understanding of the carcinogenesis of gastric cancer. It is the accumulation of multiple gene abnormalities that result in the transformation of a normal epithelial cell to a malignant cell (55). Progressive accumulations of genetic changes have been evidenced in the different stages of 
Correa's model. Microsatellite instability $(56,57)$ and telomerase reactivation (58) occurred in early carcinogenesis. Mutation of p53 (59) and adenomatous polyposis coli genes (60), and amplification and overexpression of c-myc $(61,62)$ and cyclin E genes (63) are found in advanced gastric cancer. Unlike colon and pancreatic cancers, gastric cancer rarely involves k-ras mutation (64). Multiple autocrine and paracrine loops interact with each other in the progression of advanced gastric cancer. These include hepatocyte growth factor (65) and the c-met gene (66); fibroblast growth factor and the k-sam gene (67); epidermal growth factor and the c-erbB-2 or HER-2/neu genes (6871); and epidermal growth factor (EGF)/transforming growth factor-alpha and EGF receptors (72). In addition, Ecadherin $(73,74)$, and $\operatorname{CD} 44(75,76)$ have been shown to play an important role in metastasis.

Genetics events further reinforced the observation that two different pathways exist in the intestinal and diffuse types of gastric cancer. Mutations of the $p 53$ gene were essentially restricted to the intestinal type in the early phase but were involved in both types in the advanced stage $(77,78)$. Loss of heterozygosity, mutations of the adenomatous polyposis coli (60) and the 'deleted in colon cancer' (79) genes, and amplification of the c-erbB-2 gene (67) were frequently associated with intestinal-type gastric cancers but were seldom found in the diffuse type. Microsatellite instability was found in $64 \%$ of the diffuse type but only $17 \%$ of the intestinal type (80). Amplification of c-met and k-sam tyrosine kinase receptor genes, as well as overexpression of the EGF family, transforming growth factor-beta, platelet-derived growth factor, insulin-like growth factor-II and fibroblast growth factor, are frequently found in diffuse type carcinomas $(67,72)$. The involvement of the cadherin gene, an invasion suppressor gene, took place at an early stage in the diffuse type. Decreased expression of E-cadherin has been found in most diffuse-type gastric cancer. Germ-line mutation of the E-cadherin gene has been found in familial carcinoma of the stomach (81).

The relationship between $H$ pylori and molecular changes may be another way to study the role of $H$ pylori in gastric carcinogenesis. Kuniyasu et al (82) found that the degree of $H$ pylori infection correlated with the level of human telomerase RNA expression and telomerase positivity in 26 carcinoma tissues. Moss et al (83) showed that apoptotic cells occurred in about $2.9 \%$ of epithelial cells in uninfected gastric tissue samples, located in the most superficial aspect of gastric glands. Apoptotic cells were found in $16.8 \%$ of infected gastric tissues throughout the depth of gastric glands, and the value fell to $3.1 \%$ after $H$ pylori eradication. Similar results have been obtained by others $(84,85)$. Accumulation of mutant $\mathrm{p} 53$ protein at the regenerating zone of gastric pits was significantly decreased in the $H$ pylori-eradicated group compared with the noneradicated group (86). Downregulation of the E-cadherin protein has been shown to be significantly associated with $H$ pylori infection in patients with normal gastric mucosa, gastritis, gastric ulcer and duodenal ulcer (87). Studies on whether eradication of $H$ pylori results in reversion or halting of the molecular events is important both in the understanding of gastric carcinogenesis and in the management of patients.

\section{TREATMENT}

Surgery: The surgical strategy of the Japanese Research Society for Gastric Cancer was based on gastric lymphatic drainage. D2 radical gastrectomy has been advocated and practised as standard surgery in Japan for the past 30 years. In D2 radical gastrectomy, all of the lymph nodes are retrieved from the resection specimen and examined for micrometastasis, which sometimes may be difficult to see intraoperatively. This is in contrast to the Western world, where conventional limited D1 radical gastrectomy is more commonly performed. Japanese series demonstrated a survival benefit using D2 resection (88). However, this was not proven in the Western world (89). In a recent prospective, randomized controlled trial, D2 resections were associated with significantly higher mortality and morbidity, which may nullify the survival benefits from D2 procedures (90). Further, the difference could also be accounted for partially by understaging in the Western world, where less regional lymph nodes were resected (91). In addition, the number of tumours diagnosed in Japan could have been overstaged, because some of the stage 1 carcinomas diagnosed in Japan were reported to be dysplasia by Western pathologists (92). Endoscopic treatment: Therapeutic endoscopy for gastric cancer is a minimally invasive procedure that aims for complete cancer removal in early gastric cancer, palliation by recanalization or hemostasis of cancer bleeding. Endoscopic mucosal resection proposed by Tada et al (93) has been preformed in patients with early gastric cancer in the absence of lymph node involvement, whereas the endoscopic laser ablation technique offers high efficacy in treating deeper invasive cancers.

Chemotherapy: Adjuvant chemotherapy after curative surgery has not been able to show a prolonged disease-free interval or overall survival by meta-analysis (94). A recent prospective study compared one of the newer chemotherapy regimens, consisting of 5-fluorouracil, leucovorin and epidoxorubicin, with surgery alone in node-positive patients; the result was a significantly improved median survival and delayed time to recurrence in the chemotherapy-treated patients (95). Further follow-up to determine long term survival benefit is necessary. Neoadjuvant chemotherapy aims at reducing tumour bulk, thus downstaging the primary tumour to increase resectability rates. But at the same time, it may delay operation in those patients with early gastric cancer who do not benefit from neoadjuvant chemotherapy. Further trials on neoadjuvant chemotherapy is necessary. New second-generation combinations of chemotherapy protocols were developed for palliative care. These include etoposide plus cisplatin; methotrexate; etoposide plus 5-fluorouracil plus leucovorin; continuous infusion of 5-fluorouracil plus cisplatin; and high dose methotrexate plus 5-fluorouracil plus doxorubicin (96-98). Currently, promising results have been achieved in 
phase II studies by combining paclitaxel with other chemoagents for treating gastric cancer $(99,100)$. Further large scale evaluation is necessary.

\section{SCREENING}

Annual screening has been advocated in Japan for persons older than 50 years old using barium meal or endoscopy. This enables $40 \%$ to $50 \%$ of the tumours to be diagnosed in the early stages. This screening has been alleged to account for the recent decline in mortality from gastric cancer (88).

\section{CONCLUSIONS}

Despite the decline in incidence, gastric carcinoma still carries the second highest cancer mortality in the world. Research in molecular biology may develop prognostic markers for identifying high risk patients who require more aggressive treatments. It may also lead to the discovery of innovative therapeutic targets. For example, the study of EGF receptor antagonists is underway; these antagonists may become powerful therapeutic agents. The study of thymidilate synthase gene expression may help to identify patients who are more likely to benefit from chemotherapy.

However, in addition to searching for better treatment modalities, reducing the incidence of gastric cancer should be aimed at by primary and secondary prevention. Mass screening by endoscopy has already achieved success in Japan, which accounts for the better survival rates in Japan. The use of molecular genetics, such as microsatellite instability, may be a potentially valuable tool for identifying patients at risk for developing gastric cancer. The effectiveness of diet modification and the primary chemoprevention by $H$ pylori eradication are currently being evaluated. Hopefully, in the next century, gastric cancer will no longer be a major cause of death in the world.

\section{REFERENCES}

1. Haenszel W. Variation in incidence of and mortality from stomach cancer, with particular reference to the United States. J Natl Cancer Inst 1958;21:213-62.

2. Munoz N, Asvall J. Time trends of intestinal and diffuse types of gastric cancer in Norway. Int J Cancer 1971;8:144-57.

3. Hirayama T. Epidemiology of cancer of the stomach with special reference to its recent decrease in Japan. Cancer Res 1975;35:3460-3.

4. Piper DW. Stomach cancer. UICC Technical Report Series, vol 34. Geneva: International Union Against Cancer, 1978.

5. Waterhouse J, Muir C, Correa P, et al, eds. Cancer incidence in five continents, vol III. IARC Scientific Publication, no 15. Lyon: International Agency for Research on Cancer, 1976.

6. Zheng W, Jin F, Devesa SS, Blot WJ, Fraumeni JF, Gao YT. Declining incidence is greater for oesophageal than gastric cancer in Shanghai, People's Republic of China. Br J Cancer 1993;68:978-82.

7. Lauren $P$. The two histologic main types of gastric carcinoma: diffuse and so-called intestinal type carcinoma. Acta Pathol Microbiol Scand 1965;64:31-49.

8. Ikeda Y, Mori M, Kamakura T, Haraguchi Y, Saku M, Sugimachi K. Improvements in diagnosis have changed the incidence of histological types in advanced gastric cancer. Br J Cancer 1995;72:424-6.

9. Dupont JB, Lee JR, Burton GR, et al. Adenocarcinoma of the stomach: review of 1497 cases. Cancer 1978;41:941-7.

10. Adashek K, Sanger J, Longmire WP Jr. Cancer of the stomach. Review of consecutive ten year intervals. Ann Surg 1979;189:6-10.

11. Kampschoer GHM, Nakajima T, Van De Velde CJH. Changing patterns in gastric adenocarcinoma. Br J Surg 1989;76:914-6.
12. Powell J, McConkey CC. Increasing incidence of adenocarcinoma of the gastric cardia and adjacent sites. Br J Cancer 1990;62:440-3.

13. Kalish RJ, Clancy PE, Orringer MB, Appelman HD.

Clinical, epidemiologic, and morphologic comparison between adenocarcinomas arising in Barrett's esophageal mucosa and in the gastric cardia. Gastroenterology 1984;86:461-7.

14. Wynder EL, Kmet J, Dungal N, et al. An epidemiologic investigation of gastric cancer. Cancer 1963;16:1461-96.

15. Correa P, Haenszel W, Tannenbaum S. Epidemiology of gastric carcinoma: review and future prospects. Natl Cancer Inst Monogr 1982;62:129-34.

16. Wong BCY, Ching CK, Lam SK, et al. Differential north to south gastric cancer-duodenal ulcer gradient in China. J Gastroenterol Hepatol 1998;13:1050-7.

17. Correa P, Cuello C, Duque E. Carcinoma and intestinal metaplasia of the stomach in Colombian migrants. J Natl Cancer Inst 1970;44:297-306.

18. Cuello C, Correa P, Haenszel W, et al. Gastric cancer in Columbia. I. Cancer risk and suspect environmental agents. J Natl Cancer Inst 1976;57:1015-20.

19. Berndt H, Wildner GP, Klein K. Regional and social differences in cancer incidence of the digestive tract in the German Democratic Republic. Neoplasma 1968;15:501-15.

20. Barker DJ, Coggon D, Osmond C, Wickham C. Poor housing in childhood and high rates of stomach cancer in England and Wales. Br J Cancer 1990;61:575-8.

21. Howson CP, Hiyama T, Wynder EL. The decline in gastric cancer: epidemiology of an unplanned triumph. Epidemiol Rev 1986;8:1-27.

22. Bartsch H, O'Neill I, Hermann R. The Relevance of N-nitroso Compounds to Human Cancer. Exposures and Mechanisms. IARC Scientific Publications, no 84. Lyon: International Agency for Research on Cancer, 1987:1-663.

23. Magee PN, Montesano R, Preussmann R. N-Nitroso compounds and related carcinogens. In: Searle CE, ed. Chemical Carcinogens. American Chemical Society Monograph, no 173. Washington: American Chemical Society, 1976:491-625.

24. Druckrey H. Chemical carcinogenesis on $\mathrm{N}$-nitroso derivatives. Gann Monogr 1975;17:107-32.

25. Bulay O, Mirvish SS, Garcia H, et al. Carcinogenicity test of six nitrosamides and a nitro-cyanamide administered orally to rats. J Natl Cancer Inst 1979;62:1523-8.

26. Ruddell WS, Bone ES, Hill MJ, et al. Pathogenesis of gastric cancer in pernicious anaemia. Lancet 1978;i:521-3.

27. Jones SM, Davies PW, Savage A. Gastric-juice nitrite and gastric cancer. Lancet 1978;i:1355.

28. Stewart HL. Experimental alimentary tract cancer. Natl Cancer Inst Monogr 1967;25:199-217.

29. Schlag P, Bockler R, Ulrich $\mathrm{H}$, et al. Are nitrite and $\mathrm{N}$-nitroso compounds in gastric juice risk factors for carcinoma in the operated stomach? Lancet 1980;i:727-9.

30. Frazer P, Chilvers C, Beral V, et al. Nitrate and human cancer: a review of the evidence. Int J Epidemiol 1980;9:3-11.

31. Haenszel W, Kurihara M, Segi M, et al. Stomach cancer among Japanese in Hawaii. J Natl Cancer Inst 1972;49:969-88.

32. Sato T, Fukuyama T, Suzuki T, et al. Studies of the causation of gastric cancer. 2 . The relation between gastric cancer mortality rate and salted food intake in several places in Japan. Bull Inst Public Health (Jpn) 1959;8:187-98.

33. Tatematsu M, Takahashi M, Hanaouchi M, Shirai T. Effects in rats of sodium chloride on experimental gastric cancers induced by $\mathrm{N}$-methyl-N-Nitro-N-nitrogoguanidine or 4-nitroquinoline-1-oxide. J Natl Cancer Inst 1975;55:101-6.

34. Takahashi M, Kokubo T, Furukawa F, et al. Effects of sodium chloride, saccharin, phenobarbital and aspirin on gastric carcinogenesis by N-methyl-N-Nitro-N-nitrogoguanidine. Gann 1984;75:494-501.

35. Hanawa K, Yamada S, Suzuki H, et al. Effects of sodium chloride on gastric cancer induction by $\mathrm{N}$-methyl-N-Nitro-N-nitrogoguanidine (MNNG) in rats. Proceedings of the Thirty-Ninth Annual Meeting of the Japanese Cancer Association. Tokyo: Japanese Cancer Association, 1980:49.

36. Joossens JV, Hill MJ, Elliott P, et al. Dietary salt, nitrate and stomach cancer mortality in 24 countries. Int J Epidemiol 1996;25:494-504.

37. IARC Working Group on the Evaluation of Carcinogenic Risks to Humans, Schistosomes, Liver Flukes and Helicobacter pylori. IARC Monographs on the Evaluation of Carcinogenic Risks to Humans, vol 61. Lyon: International Agency for Research on Cancer, 1994. 
38. Correa P. The gastric precancerous process. Cancer Surv $1983 ; 2: 437-50$.

39. Correa P. A human model of gastric carcinogenesis. Cancer Res 1988;48:3554-60.

40. Kikuchi S, Wada O, Nakajima T, et al. Serum anti-Helicobacter pylori antibody and gastric carcinoma among young adults. Cancer 1995; 75:2789-93.

41. Parsonnet J, Friedman GD, Vandersteen DP, et al. Helicobacter pylori infection and the risk of gastric carcinoma. N Engl J Med 1991;325:1127-31.

42. Wong BCY, Lam SK, Ching CK, et al. Differential Helicobacter pylori infection rates in two contrasting gastric cancer risk regions of South China. J Gastroenterol Hepatol 1999;14:120-5.

43. Nomura AMY, Stemmermann GN, Chyou P, et al. Helicobacter pylori infection and gastric carcinoma in a population of Japanese Americans in Hawaii. N Engl J Med 1991;325:1132-6.

44. Talley NJ, Zinsmeister AR, Weaver A, et al. Gastric adenocarcinoma and Helicobacter pylori infection. J Natl Cancer Inst 1991;83:1734-9.

45. Forman D, Newell DG, Fullerton F, et al. Association between infection with Helicobacter pylori and risk of gastric cancer: evidence from a prospective investigation. BMJ 1991;302:1302-5.

46. Eurogast Study Group. An international association between Helicobacter pylori infection and gastric cancer. Lancet 1993;341:1359-62.

47. Forman D. Helicobacter pylori infection: a novel risk factor in the etiology of gastric cancer. J Natl Cancer Inst 1991;83:1702-3.

48. Tsugane ZS, Tei Y, Takahashi T, Watanabe S, Sugano K. Salty food intake and risk of Helicobacter pylori infection. Jpn J Cancer Res 1994;85:474-8.

49. Schorah CJ, Sobala GM, Sanderson M, Collis N, Primrose JN. Gastric juice ascorbic acid: effects of disease and implications for gastric carcinogenesis. Am J Clin Nutr 1991;53(Suppl):287S-93S.

50. Graham DY, Malaty HM, Evans DG, Evans DJ Jr, Klein PD, Adam E Epidemiology of Helicobacter pylori in an asymptomatic population in the United States. Gastroenterology 1991;100:1495-501.

51. Forman D. Lessons from ongoing intervention studies. In: Hunt RH, Tytgat GNJ, eds. Helicobacter pylori: Basic Mechanisms to Clinical Care, 1998. Dordrecht: Kluwer Academic Press, 1998:354-60.

52. Hansen S, Melby KK, Aase S, Jellum E, Vollset SE. Helicobacter pylori infection and risk of cardia cancer and non-cardia gastric cancer. A nested case-control study. Scand J Gastroenterol 1999;34:353-60.

53. Coggon D, Barker DJ, Cole RB, Nelson M. Stomach cancer and food storage. J Natl Cancer Inst 1989;81:1178-82.

54. La Vecchia C, Negri E, D’Avanzo E, Franceschi S. Electric refrigerator use and gastric cancer risk. Br J Cancer 1990;62:136-7.

55. Vogelstein B, Fearon ER, Hamilton SR, et al. Genetic alterations during colorectal-tumour development. N Engl J Med 1988;319:525-32

56. Strickler JG, Zheng J, Shu Q, Burgart LJ, Alberts SR, Shibata D. P53 mutations and microsatellite instability in sporadic gastric cancer: when guardians fail. Cancer Res 1994;54:4750-5.

57. Semba S, Yokozaki H, Yamamoto S, Yasui W, Tahara E. Microsatellite instability in precancerous lesions and adenocarcinomas of the stomach. Cancer 1996;77:1620-7.

58. Tahara E, Kuniyasu H, Yasui W, Yokozaki H. Gene alterations in intestinal metaplasia and gastric cancer. Eur J Gastroenterol Hepatol 1994;6(Suppl 1):S97-101.

59. Rhyu M-G, Park W-S, Jung Y-J, Chooi S-W, Meltzer SJ. Allelic deletions of MCC/APC and p53 are frequent late events in human gastric carcinogenesis. Gastroenterology 1994;106:1584-8.

60. Nakatsuru S, Yanagisawa A, Ichii S, et al. Somatic mutation of the APC gene in gastric cancer: frequent mutations in very well differentiated adenocarcinoma and signet-ring cell carcinoma. Hum Mol Genet 1992;1:559-63.

61. Shibuya M, Yokota J, Ueyama Y. Amplification and expression of a cellular oncogene (c-myc) in human gastric adenocarcinoma cells. Mol Cell Biol 1985;5:414-8.

62. Ciclitira PJ, Macartney JC, Evan G. Expression of c-myc in nonmalignant and pre-malignant gastrointestinal disorders. J Pathol 1987;151:293-6.

63. Akama Y, Yasui W, Yokozaki H, et al. Frequent amplification of the cyclin E gene in human gastric carcinomas. Jpn J Cancer Res 1995;86:617-21.

64. Nanus DM, Kelsen DP, Mentle IR, Altorki N, Albino AP. Infrequent point mutations of ras oncogenes in gastric cancers. Gastroenterology 1990;98:955-60.
65. Taniguchi T, Kitamura M, Iwasaki Y, Yamamoto Y, Igari A, Toi M. Increase in the circulating level of hepatocyte growth factor in gastric cancer patients. Br J Cancer 1997;75:673-7.

66. Kuniyasu H, Yasui W, Kitadai Y, Yokozaki H, Ito H, Tahara E. Frequent amplification of the c-met gene in schirrhous type stomach cancer. Biochem Biophys Res Commun 1992;189:227-32.

67. Tahara E. Molecular mechanism of stomach carcinogenesis. J Cancer Res Clin Oncol 1993;119:265-72.

68. Akiyama T, Sudo C, Ogawara H, Toyoshima K, Yamamoto T. The product of the human c-erbB-2 gene: a 185-kilodalton glycoprotein with tyrosine kinase activity. Science 1986;232:1644-6.

69. Coussens L, Yang-Feng TL, Liao YC, et al. Tyrosine kinase receptor with extensive homology to EGF receptor shares chromosomal location with neu oncogene. Science 1985;230:1132-9.

70. Kameda T, Yasui W, Yoshida K, et al. Expression of ERBB2 in human gastric carcinomas: relationship between p185ERBB2 expression and the gene amplification. Cancer Res 1990;50:8002-9.

71. Tal M, Wetzler M, Josefberg Z, et al. Sporadic amplification of the HER2/neu protooncogene in adenocarcinomas of various tissues. Cancer Res 1988;48:1517-20.

72. Tahara E. Growth factors and oncogenes in human gastrointestinal carcinoma. J Cancer Res Clin Oncol 1990;116:121-31.

73. Shimoyama Y, Hirohashi S. Expression of E- and P-cadherin in gastric carcinomas. Cancer Res 1991;51:2185-92.

74. Mayer B, Jauch KW, Gunthert U, et al. De-novo expression of CD44 and survival in gastric cancer. Lancet 1993;342:1019-22.

75. Yokozaki H, Ito R, Nakayama H, Kuniyasu H, Taniyama K, Tahara E. Expression of CD44 abnormal transcripts in human gastric carcinomas. Cancer Lett 1994;83:229-34.

76. D'Errico A, Garbisa S, Liotta LA, Castronovo V, Stetler-Sterenson WG, Grigioni WF. Augmentation of type IV collagenase, laminin receptor, ki67 proliferative antigen associated with human colon, gastric, and breast carcinoma progression. Mod Pathol 1991;4:239-46.

77. Ranzani GN, Luinetti O, Padovan LS, et al. p53 gene mutations and protein nuclear accumulation are early events in intestinal type gastric cancer but late events in diffuse type. Cancer Epidemiol Biomarkers Prev 1995;4:223-31.

78. Uchino S, Noguchi M, Ochiai A, Saito T, Kobayashi M, Hirohashi S. p53 mutation in gastric cancer: a genetic model for carcinogenesis is common to gastric and colorectal cancer. Int J Cancer 1993;54:759-64.

79. Uchino S, Tsuda H, Noguchi M, et al. Frequent loss of heterozygosity at the DCC locus in gastric cancer. Cancer Res 1992;52:3099-102.

80. Han HJ, Yanagisawa A, Kato Y, Park JG, Nakamura Y. Genetic instability in pancreatic cancer and poorly differentiated type of gastric cancer. Cancer Res 1993;53:5087-9.

81. Guilford P, Hopkins J, Harraway J, et al. E-cadherin germline mutations in familial gastric cancer. Nature 1998;392:402-5.

82. Kuniyasu H, Domen T, Hamamoto T, et al. Expression of human telomerase RNA is an early event of stomach carcinogenesis. Jpn J Cancer Res 1997;88:103-7.

83. Moss SF, Calam J, Agarwal B, Wang S, Holt PG. Induction of gastric epithelial apoptosis by Helicobacter pylori. Gut 1996;38:498-501.

84. Jones NL, Shannon PT, Cutz E, Yeger H, Sherman PM. Increase in proliferation and apoptosis of gastric epithelial cells early in the natural history of Helicobacter pylori infection. Am J Pathol 1997;151:1695:703.

85. Bravo LE, Mannick EE, Zhang X-J, Ruiz B, Correa P, Miller MJS. $H$ pylori infection is associated with inducible nitric oxide synthase expression, nitrotyrosine and DNA damage. Gastroenterology 1995;108:A63. (Abst)

86. Hibi K, Mitomi H, Koizumi W, Tanabe S, Saigenji K, Okayasu I. Enhanced cellular proliferation and p53 accumulation in gastric mucosa clinically infected with Helicobacter pylori. Am J Clin Pathol 1997;108:26-34.

87. Terres AM, Pajares JM, O'Toole D, Ahern S, Kelleher D. H pylori infection is associated with downregulation of E-cadherin, a molecule involved in epithelial cell adhesion and proliferation control. J Clin Pathol 1998;51:410-2.

88. Maruyama K, Okabayashi K, Kinoshita T. Progress in gastric cancer surgery in Japan and its limits of radicality. World J Surg 1987;11:418-25.

89. Wanebo HJ, Kennedy BJ, Winchester DP, Fremgen A, Stewart AK. Gastric carcinoma: does lymph node dissection alter survival? J Am Coll Surg 1996;183:616-24.

90. Cuschieri A, Fayers P, Fielding J, et al. Postoperative morbidity and mortality after D1 and D2 resections for gastric cancer: preliminary 


\section{Chan et al}

results of the MRC randomised controlled surgical trial. The Surgical Cooperative Group. Lancet 1996;347:995-9.

91. Bunt A, Herman J, Smit V, van de Velde C, Fleuren G, Bruijn J. Surgical/pathologic-stage migration confounds comparisons of gastric cancer survival rates between Japan and Western countries. J Clin Oncol 1995;13:19-25.

92. Schlemper RJ, Itabashi M, Kato Y, et al. Differences in diagnostic criteria for gastric carcinoma between Japanese and Western pathologists. Lancet 1997;349:1725-9.

93. Tada M, Murata M, Takemoto T, et al. Development of 'strip-off' biopsy. Gastroenterol Endosc 1994;26:833-9.

94. Hermans J, Bonenkamp JJ, Boon MC, et al. Adjuvant therapy after curative resection for gastric cancer: meta-analysis of randomised trials. J Clin Oncol 1993;11:1441-7.

95. Neri B, de Leonardis V, Romano S, et al. Adjuvant chemotherapy after gastric resection in node-positive cancer patients: a multi-centre randomised study. Br J Cancer 1996;73:549-52.
96. Preusser P, Wilke H, Achterrath W, et al. Phase II study with the combination etoposide, doxorubicin, and cisplatin in advanced measurable gastric cancer. J Clin Oncol 1989;7:1310-7.

97. Stahl M, Wilke H, Preusser P, et al. Etoposide, leucovorin and 5-flurouracil (ELF) in advanced gastric carcinoma - final results of a phase II study in elderly patients or patients with cardiac risk. Onkologie 1991;14:314-8

98. Wilke H, Preusser P, Fink U, et al. New developments in the treatment of gastric carcinoma. Semin Oncol 1990;17(1 Suppl 2):61-70.

99. Lokich JJ, Sonneborn H, Anderson NR, et al. Combined paclitaxel, cisplatin, and etoposide for patients with previously untreated esophageal and gastroesophageal carcinomas. Cancer 1999;85:2347-51.

100. Kim YH, Shin SW, Kim BS, et al. Paclitaxel, 5-fluorouracil, and cisplatin combination chemotherapy for the treatment of advanced gastric carcinoma. Cancer 1999;85:295-301. 


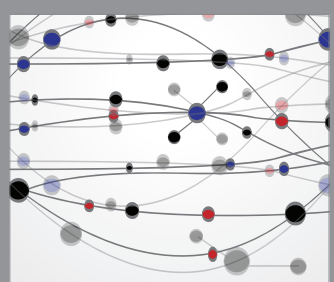

The Scientific World Journal
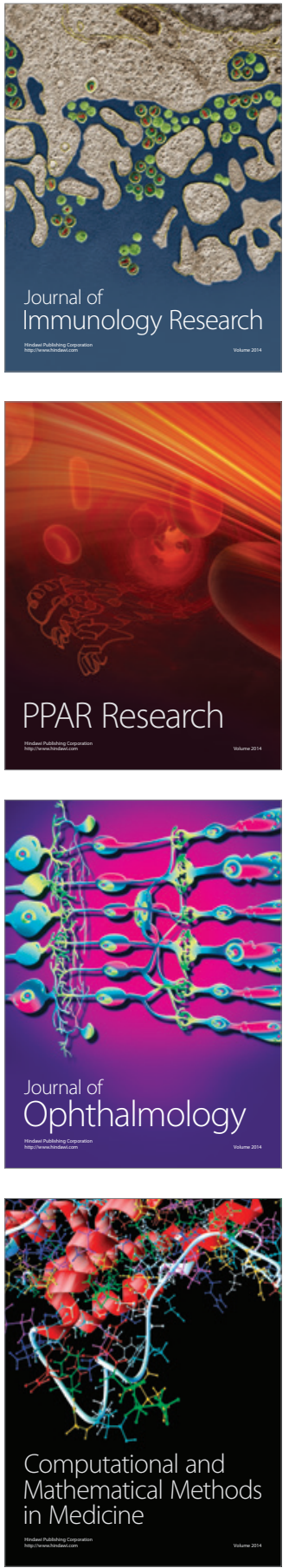

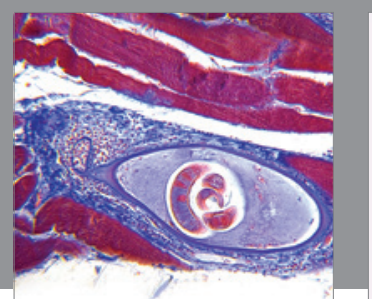

Gastroenterology Research and Practice

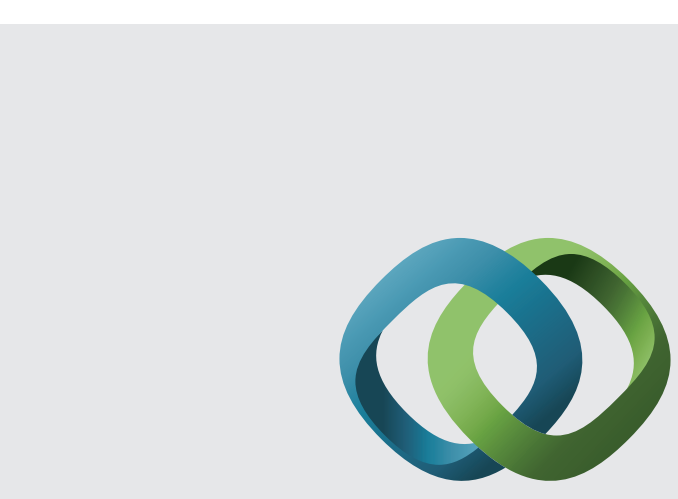

\section{Hindawi}

Submit your manuscripts at

http://www.hindawi.com
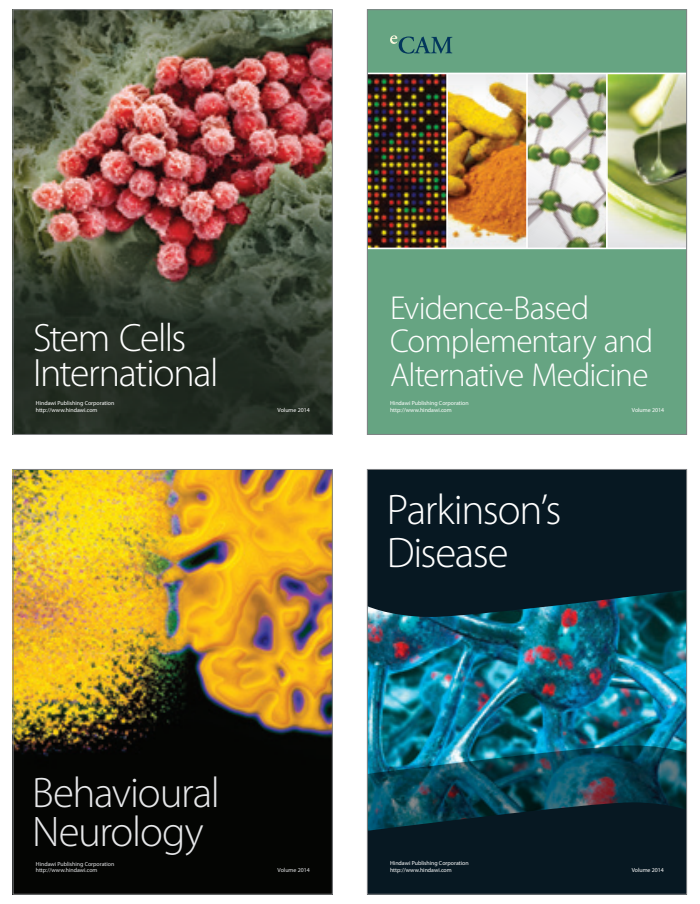
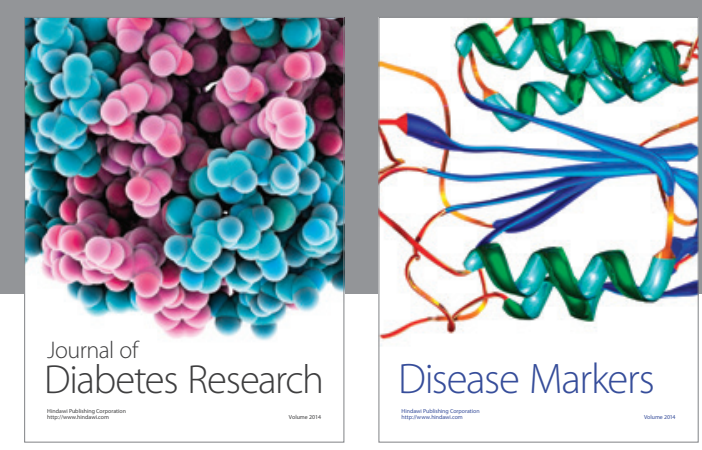

Disease Markers
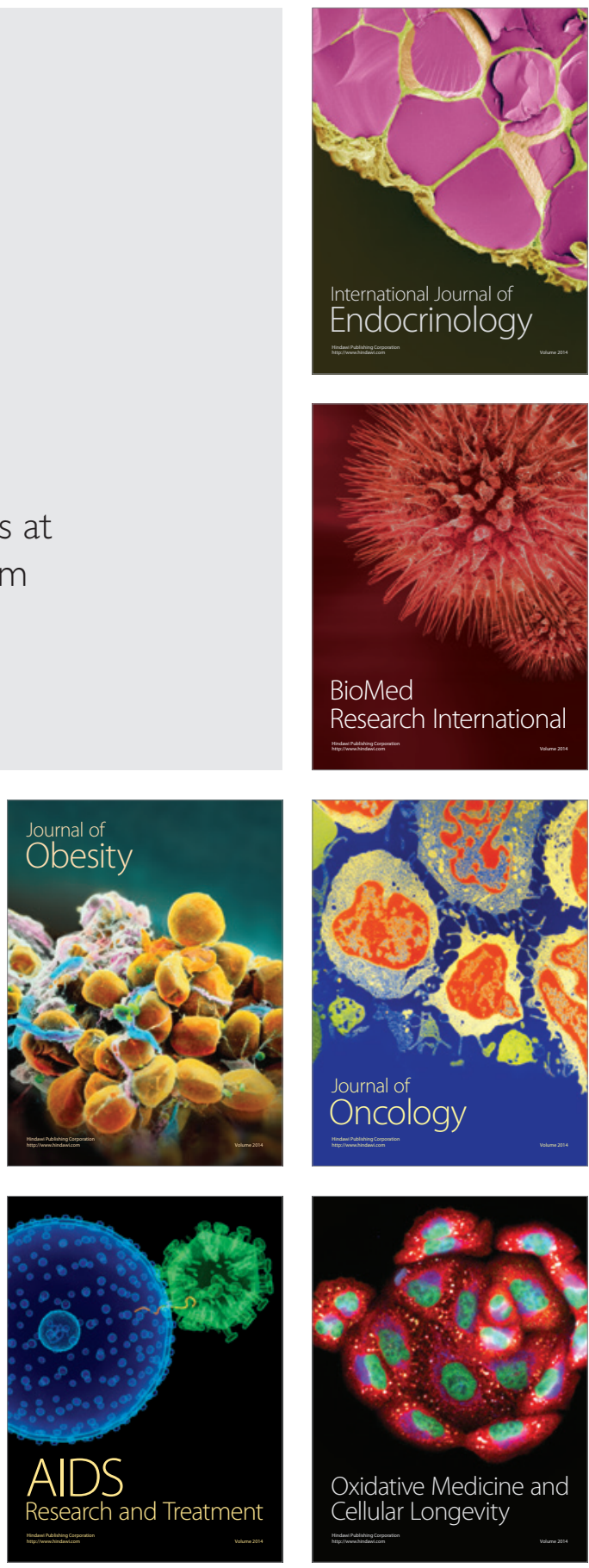